\title{
Moving Peoples in the Early Roman Empire ${ }^{1}$
}

\author{
Greg Woolf
}

\section{$1 \quad$ Six Thousand Years of Enclosure}

The opening pages of James C. Scott's The Art of Not Being Governed offer a global account of the political economy and ecology of early states. The first states, for Scott, were miniscule authoritarian regimes nestled on arable plains and plateaux and surrounded by vast ungoverned peripheries of mountain, marshland, swamp, steppe and desert. Around them peripheral populations were both natural trading partners - because the ecologies of their respective homes were so different - and a constant threat. Peripheral populations posed a double threat in fact since they not only periodically raided the plains, but also represented an alternative, freer way of life, an object lesson in "the art of not being governed".

For Scott, whose expertise is in the societies of South East Asia, the story of the last six thousand years has been one of enclosure. States have strived to tame their peripheral 'barbarians', subjecting them to taxes and the levy, to slavery and government. Subjected peoples were put to work to increase the agricultural surpluses on which states depended and to build the monuments that now constitute the principal record of their efforts. That history of enclosure has been a discontinuous one, since in the remote past states often collapsed, their subject populations melting away into the forests and mountains until the next episode of state building. Only in the last few centuries has the option of avoiding the state altogether more or less disappeared. But for most of history there has been a range of social options. ${ }^{2}$

To historians of the ancient Mediterranean world the proposition that ancient state building was all about enclosing human populations and putting them to work is unfamiliar. When we write about expansion we usually mean the acquisition of territory, and we often treat its inhabitants as encumbrances

1 I am grateful to those who heard and responded to the presentation in Rome, to this volume's editors and also to Myles Lavan and Francisco Pina Polo for providing me with additional material and comment.

2 J.C. Scott, The Art of Not being Governed. An Anarchist History of Upland Southeast Asia (New Haven 2009). 
that came with it. Like nineteenth- and twentieth-century empire builders we think of expansion in terms of the conquest of new land, as a forced transfer of property. Slogans such as 'the sun never sets on the Union flag' presupposed a geographical and territorial notion of empire. Mostly we apply the same idiom to the ancient world, channelling some (but not all) of the ways that ancient sources described the process. ${ }^{3}$ Caesar, we repeat, conquered the whole of Gaul, and was the first to take Roman troops across the Channel and the Rhine.

Scott invites us to think instead of Caesar as taking control of the Gaulish tribes, harnessing the warrior energies of some, and subjecting the rest to regimes of labour management that through one route or another enriched the Roman people. John Richardson showed twenty five years ago that Romans came rather late to thinking of their power in terms of its territorial extent: imperium acquires a geographical sense only at the very end of the Republican period. Other senses of the word, such as 'rule', 'dominion' and 'command' persist well into the Principate. Myles Lavan has demonstrated more recently that even during the first two centuries $\mathrm{AD}$, the language that Romans applied to their subjects derived mainly from domestic relations of subjection, rather than from their spatial marginalization. ${ }^{4}$ All the same it is difficult for us to get out of the habit of thinking of ancient states as territorially circumscribed jurisdictions - as rather like modern sovereign states in fact—despite the fact that many ancient authors wrote in terms of peoples rather than polities or spaces. Ancient ethnicities were constructed on the basis of fictive kinship, on myths of common descent, on a shared history and sometimes shared language, worship and customs: residence was rarely stressed. ${ }^{5}$ Imperium populi Romani did not describe a bounded political entity exercising jurisdiction over a portion of the globe, so much as the domination of one people over a number of subject peoples. Triumphal rhetoric and monuments typically

3 For that strand of ancient thought see C. Nicolet, L'Inventaire du monde. Géographie et politique aux origines de l'Empire Romain (Paris 1988).

4 J.S. Richardson, The Language of Empire. Rome and the Idea of Empire from the Third Century $B C$ to the Second Century AD (Cambridge 2008); idem, 'Imperium Romanum. Empire and the language of power', Journal of Roman Studies 81 (1991), 1-9; M. Lavan, Slaves to Rome. Paradigms of Empire in Roman Culture (Cambridge 2013).

5 Inter alia by J.M. Hall, Hellenicity. Between Ethnicity and Culture (Chicago 2002); E. Dench, Romulus' Asylum. Roman Identities from the Age of Alexander to the Age of Hadrian (Oxford 2005); T. Derks and N. Roymans, eds., Ethnic Constructs in Antiquity. The Role of Power and Tradition (Amsterdam 2009); N. Roymans, Ethnic Identity and Imperial Power. The Batavians in the Roman Empire (Amsterdam 2004); G. Woolf, Tales of the Barbarians. Ethnography and Empire in the Roman West (Malden, MA and Oxford 2011); S. Mitchell and G. Greatrex, eds., Ethnicity and Culture in Late Antiquity (London 2000); T. Whitmarsh, ed., Local Knowledge and Microidentities in the Imperial Greek World (Cambridge 2010). 
celebrated the conquest of peoples: the fasti triumphales mostly refer to defeated kings or populations. When attention is focused on places or citiesas on the Sebasteion of Aphrodisias or the Temple of Hadrian in Rome-provinces and cities are typically personified, creating what Bert Smith has called simulacra gentium. ${ }^{6}$

Despite these considerations, it turns out to be quite difficult to write about the Roman empire as one chapter in a global history of enclosure. Our default modes of analysis depend either on legalistic/constitutional concepts inherited from the nineteenth century, or else on a political economy paradigm which is good at charting the extraction and redistribution of material resources, but poor at describing Roman biopower. One possibility is that historians of western antiquity have simply become used to using a different set of conceptual frameworks to describe and analyse state-building and the origins of empires than their counterparts who work on eastern Asia. But if that were the case then with a little ingenuity we could rephrase our questions in their terms.

But the problem is more fundamental than that. It is in fact rather difficult to find examples of Roman emperors transplanting entire populations from one part of their realm to another, or putting subject populations to work on great capital projects in the way that other empires did. Romans could certainly imagine power exercised in that way, indeed it was a part of the stereotype of tyranny that they inherited from Greek historiography. The tradition of how 'La Grande Roma dei Tarquinii' was built fits the pattern happily. ${ }^{7}$ Yet Rome's emperors seem to have refrained from moving their subjects about in this way. This paper asks why this was the case.

Just how unusual Rome was in this respect emerges from consideration of some other early empires. The Qin Emperor of China reputedly mobilized huge numbers to work on the Great Wall, to construct the Ling canal to link the Pearl and Yangtze River systems, to build roads, royal palaces and famously his mausoleum at Lishan. The terracotta army, which comprises many more

6 R.R.R Smith, 'Simulacra gentium: The ethne from the Sebasteion at Aphrodisias', Journal of Roman Studies 78 (1988), 50-77; M. Sapelli, ed., Provinciae fideles. Il fregio del tempio di Adriano in Campo Marzio (Milan 1999); R.M. Schneider, Bunte Barbaren. Orientalenstatuen aus farbigem Marmor in der römischen Repräsentationskunst (Worms 1986).

7 M. Cristofani, ed., La grande Roma dei Tarquini. Roma, Palazzo delle esposizioni, 12 giugno-3o settembre 1990. Catalogo della mostra (Rome 1990). 
professions than the military alone, is in some sense a monument to the vast and varied human capital he was able to amass and deploy. As so often, early imperial habits emerged from an intensification of some aspects of pre-imperial systems. The kingdom of Qin already owed some of its wealth to the settling of convicts in Sichuan to exploit its mineral and agricultural resources. ${ }^{8}$ Later dynasties - and arguably Communist China too-continued the tradition of carrying out massive public works by obliging its subjects to work on them.

China was not an isolated case. At least some of the monumental building in Pharaonic Egypt depended on labour extracted from subject populations. The so-called workers' town at Giza for those labouring on the construction of the pyramids was likely filled through forced population transfer. Further afield the Inka derived some of their wealth from organized programmes of settlement, in effect internal colonization projects: it has been estimated that several million people were resettled during the centuries of Inka rule. ${ }^{9}$ The Mitma system transplanted populations of loyal Quechua speakers into conquered territory, while rebellious populations were deported from their homes. Census systems and officials from the central government kept track of the Inka's subjects and from these we can see some mitmaqkuna were designated miners or weavers.

In other instances, forced population movements have been inferred from other evidence. The city of Teotihuacan 30 miles northeast of what is now Mexico city was the site of major monumental building during the second and third centuries AD and remained in occupation until the middle of the sixth century. The peak population is estimated at 125,000. Almost nothing is known for sure of its history, but its exceptional scale, its intricately planned systems, its tight zoning by occupation and ethnic origin and the fact that it stood more or less alone in a rural landscape rather than at the top of a hierarchy of cities all strongly suggest that it was created by an act of political will backed by compulsory movements of population. ${ }^{10}$ Similar arguments have been advanced to account for other prehistoric cases, among them the Mound Builders of the

8 R.D.S. Yates, 'Cosmos, central authority and communities in the early Chinese Empire', in S.E. Alcock et al., eds., Empires. Perspectives from Archaeology and History (New York and Cambridge 2001) $35^{-1}-368$.

9 T. D'Altroy, 'Politics, resources and blood in the Inka Empire', in S.E. Alcock et al., eds., Empires. Perspectives from Archaeology and History (New York and Cambridge 2001), 201-226.

10 L.R. Manzanilla, 'The basin of Mexico', in C. Renfrew and P. Bahn, eds., The Cambridge World Prehistory (New York 2014), 986-1104. 
Mississipi and the great hillforts of late prehistoric Europe. Cities and large monumental complexes do sometimes emerge from more gradual processes of settlement growth and hierarchization. But it is also quite common for societies to undergo a sort of phase transition, characterised by a rapid shift from dispersed villages to a smaller number of nucleated settlements. Sometimes despotic rulers have been considered the prime movers in these ventures. On other occasions, as Norman Yoffee has argued, sudden changes were themselves probably a stimulus for state building. ${ }^{11}$

Some of these massive projects - and we could add the construction of irrigation systems, the maintenance of transport infrastructure and intensifications of agricultural production for the benefit of imperial courts and armies - could be achieved by corvée labour, by imposing obligations on populations where they already lived, or by temporary relocations. But it is also clear that many imperial regimes thought nothing of permanently moving populations from one location to another. Rome, apparently, did this very rarely. This is all the more surprising since mass deportation was employed by some powers of which Romans were very well aware: I refer to the very common use of deportation as an instrument of control by Near Eastern monarchies.

\section{3} Moving Peoples in the Ancient Near East

Moving peoples — and boasting about it - became part of the idiom of royal power during the Bronze Age. ${ }^{12}$ The first instances I have found occur in Hittite monumental inscriptions and relate to the capture of entire peoples and their relocation to places where they were put to work on behalf of the crown. It is quite unlikely the Hittites originated the practice. ${ }^{13}$ Forced relocation became a key instrument of imperial policy during the Assyrian New Kingdom. ${ }^{14}$ The history of Assyrian deportations is reconstructed almost entirely from monumental royal inscriptions, and some hyperbole has been suspected. But even if the claims of between 4 and 5 million deportees are treated with scepticism by

11 N. Yoffee, Myths of the Archaic State. Evolution of the Earliest Cities, States, and Civilizations (Cambridge and New York 2005).

12 K. Radner, 'Mass deportation: the Assyrian resettlement policy', University College London 2012, http://www.ucl.ac.uk/sargon/essentials/governors/massdeportation/ (last consulted December 2015).

13 T. Bryce, 'Anatolian states', in P.F. Bang and W. Scheidel, eds., The Oxford Handbook of the State in the Ancient Near East and Mediterranean (New York and Oxford 2013), 161-179.

14 B. Oded, Mass Deportations and Deportees in the Neo-Assyrian Empire (Wiesbaden 1979). 
some experts, the scale of the movement of people is undoubted. More than 150 deportations are attested. ${ }^{15}$ Deportation was used as a punishment for rebels. It was probably also used (very much as James C. Scott argued for South East Asia) to control semi-nomadic populations of Arameans and Chaldeans on the margins of the Land of Assur, the Assyrian homeland that was conceptually distinct from the subjugated provinces. ${ }^{16}$ The aim seems not simply to have been to punish enemies nor even to break the connections of troublesome subjects with their places of origin. One component of the rhetoric was a simple demonstration of the power of Assyria's rulers. So Assurbanipal, celebrating his wars against the Arabs:

People of both sexes, donkeys, camels, cattle and small cattle without number I brought to Assyria. The area of my whole land in its entirety they filled as far as it stretches. Camels I shared out like small cattle to the people of Assyria. ${ }^{17}$

Royal inscriptions did not represent deportation simply as another weapon of terror, alongside the totals of the dead they celebrated or the gruesome imagery of slaughter on the reliefs that accompany some inscriptions. Deportation was also represented as an opportunity, even a magnanimous gesture that made the deportees favoured subjects. ${ }^{18}$ In an idiom that seems very strange to Roman historians, Assyrian rulers sometimes present themselves as gardeners, exercising a kind of benign stewardship over the land and its peoples, transplanting and replanting populations with an eye to the prosperity of the land of Assur as a whole. ${ }^{19}$ More than 80 per cent of deportations seem to have brought peripheral populations into northern Assyria and there are clear links with the grandiose royal city building projects at Assur, Nimrud, Khorsabad and Nineveh. ${ }^{20}$ Deportees helped build the cities, and many were put to work farming previously unproductive lands around them. Others presumably formed part of the populations of the largest cities. The walls of Nineveh

\footnotetext{
15 Ibidem.

16 J.N. Postgate, 'The land of Assur and the yoke of Assur', World Archaeology 23.3 (1992), 247-263.

17 VAT 5660+ cited by A. Kuhrt, The Ancient Near East, c. 3000-330 BC II (London 1995), 519.

18 W.R. Gallagher, 'Assyrian deportation propaganda', State Archives of Assyria Bulletin 8 (1994), 57-65.

19 Radner 2012, op. cit. (n. 12).

20 P.R. Bedford, 'The Neo-Assyrian Empire', in I. Morris and W. Scheidel, eds., The Dynamics of Ancient Empires. State Power from Assyria to Byzantium, Oxford Studies in Early Empires (New York 2009), 30-65.
} 
enclosed around 700 ha. It is difficult to believe its inhabitants had not been assembled from a wide area.

There is a striking difference here from the way the expansion of the City of Rome is usually understood, as chaotic, organic and unplanned growth, a process that posed problems for Rome's rulers and was certainly not orchestrated by them. Our most common point of comparison, since the work of Keith Hopkins, has been with the growth of London in the eighteenth century, a process of growth that was certainly not planned. ${ }^{21}$ Hopkins saw Roman urban growth as an indirect and unintended effect of Roman conquest: it was the expenditure of booty in the city and the displacement of peasants around it by slaves captured in war, that led to urban growth. Morley's view was very similar: empire was the only thing that made a city of the size of Rome sustainable. As in the case of early modern London the authorities responded to processes already underway: those responses included censorial building and grain doles during the Republic, greater regulation and a rudimentary urban administration under the Principate. Some have suggested that some of these expedients - among them aqueduct building, measures against food crisis, better protection against flood and fires - not only made the megalopolis sustainable, but also attracted new migrants. It is difficult to assess such claims. Walter Scheidel has recently argued that many migrants came to Rome in chains. ${ }^{22}$ Even then forced immigration tends to be treated as a solution to a labour shortage (one caused by the so-called urban graveyard effect). The process was organized by would-be slave owners rather than the senate or emperor (although these groups naturally overlapped). Near Eastern megalopoleis, by contrast, and the deportations that filled them, are represented as projects conceived, directed and realized by kings.

The best evidence for mass population movements in the Neo-Assyrian Empire is from the eighth and seventh centuries BC, from the reigns of Tiglath-Pileser III, Shalmaneser v, Sargon II, Sennacherib, Esarhaddon and Assurbanipal. How successful mass deportations were either in increasing

21 K. Hopkins, 'Taxes and trade in the Roman empire, 200 BC-AD 200', Journal of Roman Studies 70 (1980), 101-125; idem, Conquerors and Slaves. Sociological Studies in Roman History I (Cambridge 1978); idem, 'Economic growth and towns in Classical Antiquity', in Ph. Abrams and E.A. Wrigley, eds., Towns in Societies. Essays in Economic History and Historical Sociology (Cambridge 1978), 35-77; idem, 'Introduction', in P. Garnsey, K. Hopkins and C.R. Whittaker, eds., Trade in the Ancient Economy (London 1983), ix-xxv; N. Morley, Metropolis and Hinterland. The City of Rome and the Italian Economy 200 B.C.A.D. 200 (Cambridge 1996).

22 W. Scheidel, 'Human mobility in Roman Italy II: the slave population', Journal of Roman Studies 95 (2005) 64-79. 
the productivity of northern Assyria or in strengthening the state is not clear. But the practice of deportation survived the fall of Assyria in 612 вс. The Babylonian Captivity of the Jews in 586 BC is the only episode documented from the point of view of the deportees. The symbolic place the Exile occupies in a long tradition of displacements from the Land of Israel, second only to the captivity in Egypt, has obscured some important features. ${ }^{23}$ First of all this was not the first occasion on which an attempt was made to bring the population of Jerusalem into Mesopotamia. Gallagher quotes from Kings II the speech made by an Assyrian general besieging the city in the reign of Hezekiah.

... for thus says the king of Assyria: 'Make peace with me and come forth to me and eat, each from his vine and each from his fig tree and drink, each from the water of his well, -when I come and take you to a land like your land, a land of grain and wine, a land of bread and vineyards, a land of olive oil and honey, and you will live and not die, but do not listen to Hezekiah because he is inciting you.'24

The most obvious inference is that the population of Israel was regarded as an asset to be acquired. This speech is reasonably understood as propaganda, but it does not follow that some deportees did not at least eventually reconcile themselves to their new homes. Once again the Jewish experience is revealing. While the biblical narrative focuses on the return and rebuilding of Jerusalem under Nehemiah, under the patronage of a god-fearing Persian monarch, it is also well known that many Jews remained in Babylonia. The Book of Tobit begins by describing how Tobit had been deported from Galilee and resettled in Nineveh during the reign of the Assyrian king Shalmaneser, and goes on to describe his and his son Tobias' travels back and forth to their relative in Ecbatana in Media. The book was probably composed in the Hellenistic period, but there is perhaps no reason to distrust the picture it assumes of a scattered Israel under the last Assyrian Monarchs. Under the Achaemenid Empire we find Jewish settlement even more widespread. From the end of the fifth century вС an archive of documents in Aramaic attests the presence of a Jewish military colony in Egypt: when it arrived is not certain but an Achaemenid

23 On the tendency of Jewish historiography to seek cyclical patterns in history by equating for example Babylon and Rome, see N.R.M. de Lange, 'Jewish attitudes to the Roman empire', in P. Garnsey and C.R. Whittaker, eds., Imperialism in the Ancient World (Cambridge 1978), 255-281.

24 II Kings 18: 31-2. Gallagher 1994, op. cit. (n. 18), 4. 
date is perhaps most likely, although the letters refer to a Jewish Temple at Elephantine in the sixth century вс. ${ }^{25}$

Achaemenid rulers made less of deportation in their imperial rhetoric. The Cyrus Cylinder, made in the 530s BC, declared that on his accession Cyrus had returned all the captive gods and their peoples to their own lands on the instructions of Marduk, the High God of Babylon. All the same there is ample evidence of population displacements. ${ }^{26}$ The Encyclopaedia Iranica notes Cambyses transplanting 6000 Egyptians to Susiana, Darius I moving Barcaeans from north Africa to Bactria and Paeonians from Thrace to Anatolia, to say nothing of many displaced Greeks and Phoenicians. Recipients of rations listed on the Persepolis Fortification Tablets show labourers were still routinely identified by their ethnic, as are many individuals named in documents from Late Period and Ptolemaic Egypt. Achaemenid successor states continued to settle subjects in distant locations. According to Pliny the Elder those Romans captured by the Parthians at Carrhae-which Plutarch gives as 10,000 in number-were resettled in Margiana. ${ }^{27}$ The much later foundation of Ctesiphon by Chosroes I in the sixth century AD was described as a city for those he had captured in his campaigns against the Byzantines. Perhaps we should also include here the settlements of Macedonian and Thracian katoikoi in the core territories of the Seleukid kingdom, and the Greek poleis created all over the Hellenistic world by Alexander and his successors. ${ }^{28}$ The foundation of Alexandria in Egypt must have resembled the great city building projects of Assyrian and Iranian kings much more than the incremental organic growth posited for imperial Athens and Rome. ${ }^{29}$

25 J.M. Modrzejewski, The Jews of Egypt. From Rameses II to the emperor Hadrian (Edinburgh 1995), 21-44; B. Porten, The Elephantine Papyri in English. Three Millennia of Cross-cultural Continuity and Change (Leiden 1996).

26 A. Shahpur Shahbazi, 'Deportations. i. in the Achaemenid period', Encyclopaedia Iranica vir fasc. 3 (1994), 297-312; available online at http://www.iranicaonline.org/articles/ deportations\#ptı (last consulted December 2015).

27 Plut. Crass. 31; Plin. NH. 6.18 (47).

28 Seleukid military colonies: B. Bar Kohkva, The Seleucid Army. Organization and Tactics in the Great Campaigns (Cambridge 1976) 20-48.

29 The manner (and even the chronology) of the foundation of Alexandria in Egypt is very unclear. W. Scheidel, 'Creating a metropolis: a comparative demographic perspective', in W.V. Harris and G. Ruffini, eds., Ancient Alexandria between Egypt and Greece (Leiden 2004), 1-31 poses the problem neatly and suggests some possible answers. 
Had Roman emperors wished to move their subjects around there were other models they might have followed besides those provided by the monarchies of the Ancient Near East. Within the Mediterranean world there were already traditions of synoecism and colonization that might been developed further. Yet after the reign of Augustus, there were apparently few attempts to build on these traditions as a means of deploying the empire's human capital where it might best serve imperial ambitions.

Forced synoecisms appeared for the first time around the middle of the last millennium BC. Up until that point urban systems seem to have formed around the Mediterranean in a less planned and more organic way, a process closely connected with agricultural expansion, demographic growth and the connecting up of Iron Age communities around the inland sea. Cities formed first as nodes at key points of connection between long-distance exchange partners. What used to be termed Greek, Phoenician and Etruscan colonies now often seem like collaborative projects between various groups of incomers and local chieftains. Similar dynamics probably lay behind what are traditionally seen as indigenous paths to urbanism in Spain and southern Gaul, Sicily and central Italy. The cities that emerged from these collaborations were typically very small indeed by the standards of the ancient Near East, their populations numbering a few thousand individuals in most cases. Even under the Principate only one in four of the two thousand odd cities in the empire had more than 5,00o inhabitants. Gentle hierarchies and loose networks emerged naturally from traffic between these micro-cities. ${ }^{30}$

From the fourth century $\mathrm{BC}$ autocrats of different kinds began to intervene in these urban networks. Among these interventions were forced mergers of cities engineered by 'tyrants' in Sicily; attempts to obliterate ancient cities (e.g. Mitylene, nearly, in the fifth century and Thebes in the fourth, then Carthage and Corinth in the second century BC at the hands of Rome); the creation of royal centres like Cassandreia and Demetrias; the refoundation of ancient cities such as Ephesos by Hellenistic kings; and the foundation of new cities within conquered Persian territory by Alexander and his successors. What made this possible was the growth of some polities at the expense of others. But it is less clear why meddling with the urban network was thought desirable or sensible. One contributory factor may have been the reification of the polis as a political ideal. The polis appears in fifth century historiography and

30 Some suggestive ideas are contained in I. Malkin, A Small Greek World. Networks in the Ancient Mediterranean (New York 2011). 
fourth century philosophy as both an idealtype and also as a set of normative institutions. The idea that founding urban centres was the act of political creation par excellence presumes an identification of city and state. Ian Morris has argued that state formation came relatively late to the Greek world-centuries after urbanism in fact-and therefore that the city-state proper emerged only in the sixth and fifth centuries BC. ${ }^{31}$ Maybe before this point reconfiguring the political landscape did not necessarily entail restructuring the urban network. Alternatively, perhaps it was simply the growing resources of kings and other autocrats that made forced synoecisms and dispersals more common. The foundations of Megalopolis in 371 BC and of Messene in 369 BC show that monarchs were not the only engineers of synoecism. But most major cities were created and sustained by kings, tyrants or generals, and most presumably originated in the forced relocations of populations. How consciously city founders drew on Near Eastern precedent is unclear.

Arguably some Republican period colonization represents a variation on this process, the main difference being that decision making was not taken by a monarch, and that a large part of the settlers were apparently volunteers. This second proposition is traditional wisdom but might be questioned. The testimony on mid-Republican colonies suggests frequent failures, many manifested in colonists leaving their new settlements. The involvement of non-citizens in some foundations also raises questions about how far settlers were entirely free to choose. The formation of Roman Italy almost certainly did involve some forced resettlement. ${ }^{32}$

\section{5} How Romans Moved People

It is in contrast to activities of this sort that the apparent reluctance of Roman emperors to move and resettle conquered populations seems unusual. This did not mean that there was no human mobility, nor even that some of it was not indirectly a product of imperial power. But these cases seem different to the kind of relocations common elsewhere.

31 I. Morris, 'The early polis as city and state', in J. Rich and A. Wallace-Hadrill, eds., City and Country in the Ancient World (London 1991), 25-57.

32 F. Pina Polo, 'Deportation, Kolonisation, Migration. Bevölkerungsverschiebungen im republikanischen Italien und Formen der Identitätsbildung', in M. Jehne and R. Pfeilshifter, eds., Herrschaft ohne Integration? Rom und Italien in republikanischer Zeit (Frankfurt 2006), 171-206; J. Pelgrom and T. Stek, eds., Roman Republican Colonization. New Perspectives from Archaeology and Ancient History (Rome 2014). 
First, there is no doubt that many individuals were relocated during this period and some of them against their will. In this category I would include (a) many slaves, (b) some prisoners of war and hostages, and (c) those who in judicial or quasi-judicial manner were sent into exile (if they were of high status) or condemned ad metalla, to the mines, if they were not. Slaves were generally moved not by the state, but by private shippers for sale to private individuals. ${ }^{33}$ Captivi who were neither killed nor ransomed were often sold as slaves rather than retained as a workforce. Caesar's Gallic War makes clear that prisoners were often distributed as part of the booty. Josephus records a group of Jewish prisoners who were despatched to work on Nero's project at the Isthmus of Corinth. ${ }^{34}$ But otherwise there is no sign that prisoners of war were systematically put to work on state building projects. Exiles were numerically almost insignificant, even if their high status makes them highly visible in the historical record. Some were banished from Rome or Rome and Italy. From the reign of Augustus a few were banished to specific locations which they were forbidden to leave. ${ }^{35}$ Condemnation to hard labour existed, but was never practiced on a massive scale, as Rens Tacoma and Miriam Groen-Vallinga have recently confirmed. ${ }^{36}$

Second, the recruitment, deployment and resettlement of soldiers represented a major state intervention in mobility. The first experiments in this direction were rather informal creations such as Gracchuris and Lugdunum Convenarum. Both were apparently cases of peripheral imperialism, that is

33 W.V. Harris, 'Towards a study of the Roman slave trade', in J.H. D'Arms and E.C. Kopff, eds., The Seaborne Commerce of Ancient Rome (Rome 1980), 117-140; idem, 'Demography, geography and the sources of Roman slaves', Journal of Roman Studies 89 (1999), 62-75; W. Scheidel, 'Quantifying the sources of slaves in the early Roman Empire', Journal of Roman Studies 87 (1997), 156-169; J.-M. Lassère, 'La mobilité de population. Migrations individuelles et collectives dans les provinces occidentales du monde romain', in A. Akkeraz et al., eds., L'Africa romana 16. Mobilità delle persone e dei popoli, dinamiche migratorie, emigrazioni e immigrazioni nelle province occidentali dell'Impero romano. Atti del XVI convegno di studio, Rabat, 15-19 dicembre 2004 (Rome 2006), 57-92.

34 J. BJ 3.540.

35 C. Moatti, 'Immigration and cosmopolitanization', in P. Erdkamp, ed., The Cambridge Companion to Ancient Rome (Cambridge 2013), 77-92; S.T. Cohen, 'Augustus, Julia and the development of exile ad insulam,' Classical Quarterly 58.1 (2008), 206-217; M. Vallejo Girvés, J.A. Bueno Delgado and C. Sánchez Moreno Ellart, eds., Movilidad forzada entre la Antigüedad Clásica y Tardía (Madrid 2015).

36 M.J. Groen-Vallinga and L.E. Tacoma, 'Contextualizing condemnation to hard labour in the Roman Empire', in C.G. De Vito and A. Lichtenstein, eds., Global Convict Labour (Leiden 2015), 49-78; F. Millar, 'Condemnation to hard labour in the Roman Empire from the Julio-Claudians to Constantine', Papers of the British School at Rome $5^{2}$ (1984), 123-147. 
the result of ad hoc decisions made by generals on the spot rather than by the senate and people of Rome. ${ }^{37}$ It does seem likely that during the Republican period some conquered peoples were moved around in the initial aftermath of conquest. ${ }^{38}$ For the Principate, when more systematic patterns of recruitment, discharge and settlement were established, there is a broad consensus that volunteers greatly outnumbered conscripts in both legions and auxilia. ${ }^{39}$ Those legionaries who survived to achieve an honest discharge were often resettled far from their original homes. It is difficult to calculate how many did reach this state, and how frequent it was for them to take the land allocation rather than sell it and/or re-enlist.

People were moved about, then, especially in the Republican period. But these processes affected only limited sectors of society: it was not equivalent in scale to the wholesale transplantation of populations practiced by Assyrian or Inka emperors. In almost all cases we are dealing primarily with individuals, and most of them males. A few female exiles are known, and there were certainly women among trafficked slaves. But almost none of these movements affected entire families let alone entire communities or peoples. Perhaps in a few areas subject to unusually high levels of slaving or recruitment, these processes will have had a cumulative impact on social structure. The best case for this so far has been made in respect of the Batavians, a high proportion of whom were apparently recruited and then returned home at the end of their period of service..$^{40}$ Similar arguments might be developed for other groups,

37 J.S. Richardson, Hispaniae. Spain and the Development of Roman Imperialism (Cambridge 1986); H.E. Herzig, 'Novum genus hominum: Phänomene der Migratione im römischen Heer', in E. Olshausen and H. Sonnabend, eds., 'Troianer sind wir gewesen'. Migrationen in der antiken Welt. Stuttgarter Kolloquium zur Historischen Geographie des Altertums, 82002 (Stuttgart 2006), 325-328.

38 F. Pina Polo, 'Deportaciones como castigo e instrumento de colonización durante la República romana. El caso de Hispania', in F. Marco Simon, F. Pina Polo and J. Remesal Rodriguez, eds., Vivir en tierra extraña. Emigración e integración cultural en el mundo antiguo (Barcelona 2004), 211-246; idem 2006, op. cit. (n. 32); idem, 'Deportation of indigenous population as a strategy for Roman dominion in Hispania', in A. Morillo Cerdán, R. Hanel and E. Martín Hernández, eds., Limes XX. Estudios sobre la frontera romana (Madrid 2009), 281-288.

39 P.A. Brunt, 'Conscription and volunteering in the Roman imperial army', Scripta Classica Israelica 1 (1974), 90-115.

40 Roymans 2004, op. cit. (n. 5); C. van Driel-Murray, 'Those who wait at home: the effect of recruitment on women in the Lower Rhine area', in U. Brandl, ed., Frauen und Römisches Militär. Beiträge eines Runden Tisches in Xanten vom 7. bis 9Juli 2005. British Archaeological Reports International Series 1759 (Oxford 2008), 82-91. 
such as the Syrians of Intercisa, ${ }^{41}$ and perhaps for some mining areas as well. Yet, like the city of Rome, these large effects arose not from planned interventions on the part of the emperors but incidentally and consequent on the way new imperial geographies of power emerged.

The chief exceptions to the rule that emperors did not regularly move entire peoples are a few incidents in which entire tribes from outside the empire were resettled within its crystallizing frontiers. This expedient seems to have been developed on the northern frontier where, after Caesar's wars, Rome controlled large spaces through which Iron Age peoples apparently were used to wander. ${ }^{42}$ In 38 в Agrippa brought the Ubii across the Rhine and settled them in territory formerly belonging to the Eburones. ${ }^{43}$ Debate continues over whether the Tungri moved or were moved in this period. ${ }^{44}$ Strabo records Aelius Catus transplanting 50,00o Getae from across the Danube into Thrace in his own lifetime. ${ }^{45}$ An inscription from the tomb of the Plautii near Tibur, recalls how Tiberius Plautius, when governor of Moesia in the late 5os and early 6os AD, led more than 100,00o Transdanubii into the empire to make them tributary subjects along with their wives and children, their leaders or their kings. ${ }^{46}$ There have been two surveys of the settlement of northern 'barbarians' within the areas controlled directly by Roman power. ${ }^{47}$ Both conclude that after a very small number of relocations dated to the reign of Augustus and his JulioClaudian successors, there were no more instances until the reign of Marcus Aurelius. De Ste Croix finds six cases before the end of the first century CE,

41 J. Fitz, Les Syriens à Intercisa. Collection Latomus (Bruxelles 1972). The general issues are discussed by I. Haynes, Blood of the Provinces. The Roman Auxilia and the Making of Provincial Society from Augustus to Diocletian (Oxford 2013).

T.C. Champion, 'Mass migration in later prehistoric Europe', in P. Sörbom, ed., Transport Technology and Social Change. Papers Delivered at Tekniska Museet Symposium No 2, Stockholm, 1979 (Stockholm 1980), 33-42; idem, 'Protohistoric European migrations', in I. Ness, ed., Encyclopaedia of Global Human Migration (Malden MA and Oxford 2013), $2463-2468$.

43 Tac. Germ. 28-29.

44 F. Schön, 'Germanen sind wir gewesen? Bemerkungen zu den Tungri und Germani Cisrhenani und zum sogennanten taciteischen Namensatz (Tac. Germ. 2.2f.)', in E. Olshausen and H. Sonnabend, eds., 'Troianer sind wir gewesen.' Migrationen in der antiken Welt. Stuttgarter Kolloquium zur Historischen Geographie des Altertums, 82002 (Stuttgart 2006), 167-183.

45 Str. Geogr. 7.3.10.

$46 \quad$ ILS 986.

47 H. Wolff, Die Constitutio Antoniniana und Papyrus Gissensis 40 I (Köln 1976), 52-54; G.E.M. de Ste. Croix, The Class Struggle in the Ancient Greek World. From the Archaic Age to the Arab Conquests (London 1981), Appendix 3. 
another eight in the late second and early third centuries, followed by nineteen in late antiquity. The numbers only give a rough idea: most movements are attested only once, many presumably went unrecorded, and they were on a variety of scales. But the cumulative situation (Wolff's findings are similar) strongly suggests a long period in which there was no major resettlement in the north. Small scale mobility of individuals continued of course, such as the settlement of the Agri Decumates from Gaul and Germany, and of Dacia from Dalmatia. Once again all the evidence suggests these were not mass resettlements organized by the emperors. On a much smaller scale there are records of some groups in Africa settled within Roman provinces. Over all of this hangs the heavy ideological association of settled agricultural peoples and civilization, and the stigmatizing of nomads and other barbarians for their lack of moral as well as geographical fixity. 48

My conclusion is that although the emperors were well able to orchestrate deportations and projects of settlement on the whole this was not a power they chose to exercise. This marks Rome out as slightly unusual among early empires. How should we explain their reluctance or disinclination to move their subjects around?

Finding a definitive explanation for why something did not happen is always difficult. But let me close by offering a series of hypotheses.

The first can I think be rapidly dismissed but should be aired. Is it possible that Romans did not move populations out of respect for property rights or other ties between peoples and their homelands? Conceivably the negative responses to some resettlement of triumviral veterans in Italy may have deterred relocation projects in sensitive zones, but when we consider the importation of barbarian tribes, or the foundation of military coloniae like Timgad, or just the general manner in which provincials were treated, it seems a little unlikely that tact will provide the main answer. Perhaps the main argument in support of this is the increased instance of city foundations from the tetrarchy on, a period in which emperors seemed to have fewer scruples about ruling by fiat. It is true of course that the status of the city was different in the classical Mediterranean to the Ancient Near East, that emperors (like other benefactors) valued the praise lavished on them by cities, that

48 B.D. Shaw, "Eaters of flesh, drinkers of milk": the ancient Mediterranean ideology of the pastoral nomad', Ancient Society 13 (1982), 5-31. 
they were on occasion willing to grant them privileges and titles and even to be hailed as founders when they had done little to change their populations. Perhaps this 'beneficial ideology' in Vivian Nutton's phrase, did come to exercise some restraints on imperial action, so that they behaved a little less like Etruscan or Sicilian tyrants. But even if this were so (and it depends on the rather rose-tinted view of imperial power conveyed by honorific inscriptions and panegyric) this would only explain a reticence to interfere in the affairs of long-established cities. And when the emperors did wish, as they increasingly did from the late third century AD, to create great new capitals, they seem to have had no compunction in doing so.

A second possibility is that deportations and resettlements did happen but were simply not recorded. That might seem far fetched until we consider how little we know of, for instance, the date of the foundation of Alexandria in Egypt and the origins of the population that Fraser believed reached 250,000. We could ask the same question about the refoundation of Carthage and Corinth. In the latter case at least a transplantation of population from Rome seems most likely: in accordance with the general view that colonial schemes were seen as beneficial and popular projects we tend not to think of these in terms of deportation. But the truth is we know very little of the mechanics of filling new cities: Antinoopolis was apparently filled with volunteer settlers from the Fayum, ${ }^{49}$ but how widely that case can be generalized is not clear. Forced synoecism seems quite likely for the creation of new municipal capitals of the Augustan west or the cities Pompey created in Pontus. I have argued elsewhere that urbanization in parts of Gaul is difficult to envisage without some level of coercion on the part of local magnates. ${ }^{50}$ Perhaps deportation is less visible to us because unlike Assyrian kings who boasted of it as a sign of their power and also of their benevolent guardianship (gardnership?) of their subjects, Roman emperors did not feel so proud of it. The Res Gestae interestingly takes no credit for urban foundations, despite the effort invested into urban monumentality, and the creation in Nikopolis of a city-monument to the victory at Actium.

One final suggestion relates to ecology. Perhaps in the ancient Mediterranean human labour was never in as short supply as in some other parts of the world. The characteristic farming regimes of south east Asia, with which I began, were labour intensive. The rulers of states controlled the land they needed for

\footnotetext{
49 I am grateful to Rens Tacoma for this information.

5o G. Woolf, 'Urbanization and its discontents in early Roman Gaul', in E. Fentress, ed., Romanization and the City. Creations, Transformations and Failures. Journal of Roman Archaeology Supplementary Series 38 (Portsmouth, Rhode Island 2000), 115-132.
} 
rice cultivation but lacked a workforce, hence enclosure. Something similar applied in the Andes, if with different crops, because the lack of any animal traction put a premium on human labour. The ecology of northern Assyria could not have been more different, but clearly Assyrian rulers imagined that if they transplanted the right kind of settlers they could increase its productivity. Perhaps in ancient Rome a combination of widely available slave labour and also of free labourers willing to work for wages, and an environment which more often had too many people in it than too few, made the crucial difference.

London, January 2016 